\title{
Detection of Genomic Instability in Renal Cancer by Random Amplified Polymorphic DNA Analysis from Urine Sample as a Non-invasive Method: Potential Use in Diagnosis
}

\author{
Mohamed El-Far ${ }^{1 *}$, Hassan Abol-Enein ${ }^{2}$, Ashraf Zakaria ${ }^{3}$ and Mohammed El-Gedamy ${ }^{4}$ \\ ${ }^{1}$ Division of Biochemistry, Faculty of science, Mansoura University, Egypt \\ ${ }^{2}$ Division of Urology, Urology and Nephrology Center, Mansoura University, Egypt \\ ${ }^{3}$ Division of Molecular biology, Urology and Nephrology Center, Mansoura University, Egypt \\ ${ }^{4}$ Division of Molecular biology, Urology and Nephrology Center, Mansoura University, Egypt
}

Received: November 25, 2013; Accepted: December 26, 2013; Published: December 27, 2013

"Corresponding author: Mohamed A. El-Far, Division of Biochemistry, Faculty of Science, Mansoura University, Mansoura, Egypt, Tel: 20-50-2248348; Fax: 20-50-2246254; E-mail: elfarma2002@yahoo.com

\begin{abstract}
The study applied random amplified polymorphic DNA (RAPD) analysis including PCR technique in detection of genomic instability of renal cancer from urine samples as an early detective and a noninvasive method.

DNAs extracted, using manual method, from exfoliated cells in urine of 52 renal cancer patients. All yielded DNAs were amplified with the same 10-base pair random primer (BioA-09) with GC rich sequence (5'-GGGTAACGCC-3'). PCR products from RAPD analysis were electrophoretically separated in agarose gels and banding profiles were visualized by ethidium bromide staining and viewed under ultraviolet light.
\end{abstract}

Genomic alteration has been shown and included the disappearing of normal bands and appearing of new bands related to the tumor. The correlation between the genomic alteration and the histopathological types was assessed by using the $X^{2}$ test. Bands with molecular sizes $180\left(X^{2}=13.15, p<0.001\right), 250\left(X^{2}=9.524, p=0.002\right)$, and $1250\left(X^{2}=5.357, p=0.021\right)$ bp can be utilized as molecular markers for conventional renal cell carcinoma in addition to $1700 \mathrm{bp}$ utilized as molecular marker for transitional cell carcinoma of renal pelvis $(P=0.005)$. Also there is an association between the presence of $500 \mathrm{bp}$ and renal tumor as general (90.4\%).

The results of current investigation support the availability of using of RAPD-PCR analysis for screening of specific molecular markers by using Bio-A09 primer. These markers might be useful in diagnosis of renal cancer types and inspecting the tumor development.

Keywords: RAPD-PCR; Renal cancer; Bio-A09 primer; Genomic alterations, DNA

\section{Introduction}

Renal cell carcinoma (RCC) takes the third place in incidence among urologic tumors following prostate carcinoma and transitional cell carcinoma of bladder. This malignancy takes the tenth and fourteenth place among men and women, respectively.
Among urologic tumors, it is the worst in cancer specific mortality, since more than $40 \%$ of the patients with RCC die of the disease, opposite to the $20 \%$ mortality observed in prostate cancer or bladder carcinomas [1]. In Egypt, the two predominant types of renal cancers are renal cell carcinoma and Wilms' tumor in children of all malignant renal tumors, accounting as $56.78 \%$ and $37.28 \%$ respectively [2]. The organic DNA extractions like Phenol: Chloroform: Isoamyl Alcohol method is the preferred method of DNA extraction because it consistently yields higher quantity of DNA [3]. RAPD analysis is a PCR-based technique that based on enzymatic amplification of target or random DNA segments by using synthetic primer of arbitrary nucleotide sequence (10-12 $\mathrm{bp)}$. This primer anneal to complementary sequences at different genomic loci. Amplified products (usually within the $0.5-5 \mathrm{~kb}$ size range) are separated on agarose gels in the presence of ethidium bromide and demonstrated by ultraviolet transilluminator. The presence and absence of bands will be observed. If a mutation has occurred in the template DNA at the site that was previously complementary to the primer, a PCR product will not be produced, resulting in a different pattern of amplified DNA segments on the gel. The variable bands are commonly called polymorphic DNA [4]. The main advantages of RAPDs are that they are quick and easy to perform. Because PCR is involved, only low quantities of template DNA are required, usually 5-50 ng per reaction. Since random primers are commercially available, no sequence data for primer construction are needed and, radioisotopes not necessary. Moreover, RAPDs have a very high genomic abundance and large number of loci that can be screened quickly [4]. So, RAPD have also been applied in gene mapping studies to fill gaps not covered by other markers [5].

\section{Materials and Methods \\ Patients and controls}

The study was conducted in a prospective nonrandomized pattern. Voided urine samples were obtained from 52 patients 
with renal tumors admitted in Urology and Nephrology center, Mansoura University, Egypt, for treatment. Their ages ranging from $2-74$ (mean $51.07 \pm 16.84$ ). The female-to-male ratio is estimated as 1:3. Eight healthy individuals gave a urine sample to be used as a control (mean age $28.2 \pm 2.8$; 5 female, 3 male). Table 1 showed that conventional renal cell carcinoma comprised the highest percentage $(80.8 \%)$ compared to the other types.

\section{Chemicals}

Tissue Digestion buffer preparation: prepared by mixing $100 \mathrm{mM} \mathrm{NaCl}, 10 \mathrm{mM}$ Tris-HCl 'pH 8.0', 25mM EDTA 'pH 8.0' and $0.5 \%$ sodium dodecyl sulphate (SDS) to each other and stored at room temperature [6]. Lambda DNA/Hind III marker: was mixed with blue/orange $6 \mathrm{x}$ loading dye with a ratio 5:1 respectively and kept in $-20^{\circ} \mathrm{C}$. Proteinase-K preparation: the lyophilized proteinase $\mathrm{K}$ were reconstituted in sterile deionized water to a final concentration of $20 \mathrm{mg} / \mathrm{ml}$ and stored in small vials at $-20^{\circ} \mathrm{C}$ until use [7]. RNase preparation: $10 \mathrm{mg} / \mathrm{ml}$ RNase solution was prepared by dissolving $10 \mathrm{mg}$ pancreatic RNase in $10 \mathrm{mM}$ Tris$\mathrm{Cl}(\mathrm{pH} 7.5)$ and $15 \mathrm{mM} \mathrm{NaCl}$ to a final concentration of $10 \mathrm{mg} /$ $\mathrm{ml}$; boiled at $100^{\circ} \mathrm{C}$ for 15 minutes and allowed to cool slowly to room temperature before being dispensed into small aliquots and stored at $-20^{\circ} \mathrm{C}$ [7]. Tris-Acetate EDTA (50x) stock solution preparation: A $242 \mathrm{gm}$ Tris base, $57.1 \mathrm{ml}$ glacial acetic acid and $100 \mathrm{ml} 0.5 \mathrm{M}$ EDTA pH 8.0 were mixed with $800 \mathrm{ml}$ deionized water and the volume was completed to 1 liter. Tris-Acetate EDTA (1x) working solution preparation: A $20 \mathrm{ml}$ of 50x stock solution was taken and completed to1L by deionized $\mathrm{H}_{2} \mathrm{O}$ [7].

\section{Methodology}

\section{Urine sample collection}

Voided urine specimens were collected from all patients and controls into a $50 \mathrm{ml}$ sterile urine specimen container. 1-2 drops of glacial acetic acid (98\%) was added to lyse the red blood cells. Samples were centrifuged at $1500 \mathrm{xg}$ for 15 minutes to pellet the exfoliated cellular material. The supernatant was decanted and the pellet was transferred to a $1.5 \mathrm{ml}$ Eppendorf.

\section{Genomic DNA extraction}

A $700 \mu$ of digestion buffer containing $20 \mathrm{mg} / \mathrm{ml}$ proteinase $\mathrm{K}$ was added to all Eppendorfs containing pellets (to a final conc. $0.1 \mathrm{mg} / \mathrm{ml}$ ), thumbing for $3 \mathrm{~min}$ until no visible cell clumps remained and incubated overnight at $55-65^{\circ} \mathrm{C}$ in water bath till

\begin{tabular}{|r|l|l|}
\hline Histopathological subtypes & NO & \% \\
\hline A. Conventional renal cell carcinoma (RCC) & 42 (total) & 80.8 \\
\hline i. Clear renal cell carcinoma & 22 & 42.3 \\
\hline ii. Chromophobe renal cell carcinoma & 2 & 3.8 \\
\hline iii. Papillary renal cell carcinoma & 18 & 34.6 \\
\hline B. Transitional cell carcinoma of renal pelvic & 5 & 9.6 \\
\hline C. Wilms' tumor (Nephroblastoma) & 2 & 3.8 \\
\hline D. Renal sarcoma & 1 & 1.9 \\
\hline E. Renal oncocytoma & 2 & 3.8 \\
\hline
\end{tabular}

Table 1: Patients histopathological subtypes. the solution became clear. Equal volumes of Phenol: Chloroform: Isoamyl Alcohol (PCI) was added and mixed well until the phases were completely mixed. Samples were centrifuged at $13200 \mathrm{xg}$ for $10 \mathrm{~min}$ and the upper clear layer was transferred to a new sterile Eppendorf. To the clear aqueous layer, RNase solution was added to a final concentration of $20 \mu \mathrm{g} / \mathrm{ml}$, mixed thoroughly and incubated in a water bath at $37^{\circ} \mathrm{C}$ for 4 hours. An equal volume of PCI was added, mixed well and centrifuged again at $13200 \mathrm{xg}$ for $10 \mathrm{~min}$ and the upper clear aqueous layer was transferred to a new sterile Eppendorf. Sodium chloride solution was added to a final concentration of $1 \mathrm{M}$ and mixed well, then 0.6 volume of Isopropanol was added and mixed by inversion several times and kept at room temperature until DNA appeared as white floating filaments. DNA was spooled out and centrifuged at $13200 \mathrm{xg}$ for 5 minutes. The supernatant was decanted, and the DNA pellet was washed twice with $600 \mu \mathrm{l}$ of room temperature $70 \%$ ethanol. The ethanol was aspirated and the DNA pellet was air dried for 15 minutes or dried in oven at $60^{\circ} \mathrm{C}$ for overnight to obtain a dry lyophilized DNA pellet [7]. The DNA pellet rehydrated in 10-30 $\mu \mathrm{l}$ deionized water or TE buffer (according to the pellet size) for 1 hour at $65^{\circ} \mathrm{C}$ or overnight at $4^{\circ} \mathrm{C} .5 \mu \mathrm{l}$ of extracted genomic DNA was mixed with $1995 \mu$ l sterile deionized water; DNAs concentration and purity were assessed spectrophotometerically at 260 and $280 \mathrm{~nm}$. The concentration was calculated according to the standard value $(10 D 260 \mathrm{~nm}=50 \mu \mathrm{g} / \mathrm{ml}$ of dsDNA). The degree of purity of the DNA preparation was determined by the ratio of $260 \mathrm{~nm} / 280 \mathrm{~nm}$ readings, which lies between 1.8-2.0 [7]. The yielded DNA integrity was demonstrated by DNA electrophoresis on an agarose gel $(0.7 \%)$ in $1 \times$ TAE and mixed with ethidium bromide (final concentration of $0.5 \mu \mathrm{g} / \mathrm{ml}$ ).

\section{RAPD-PCR amplification protocol}

In a total volume $20 \mu \mathrm{l}, 1 \mu \mathrm{g}$ of genomic DNA extracted from urine samples of renal carcinomas or corresponding normal individuals were amplified in reaction mixture containing one PCR bead_each bead contains 1.0 unit of Taq DNA polymerase, $10 \mathrm{mM}$ Tris-HCl, (pH 9.0 at room temperature), $30 \mathrm{mM} \mathrm{KCl}$, $1.5 \mathrm{mM} \mathrm{MgCl}, 250 \mu \mathrm{M}$ of each deoxy Nucleotide Tri Phosphate (dNTPs) and stabilizers, including Bovine Serum Albumin (BSA)_ and 15 picomol of BioA-09(5'-GGGTAACGCC-3'). The reaction mixture was overlaid with $25 \mu \mathrm{l}$ of mineral oil. PCR reaction mixture was then transferred into thermal cycler programmed for 35 cycles of 1 minute at $94^{\circ} \mathrm{C}$ for DNA denaturing, 1 minute at $40^{\circ} \mathrm{C}$ for primer annealing with DNA and 2 minutes at $72^{\circ} \mathrm{C}$ for new DNA extension. A second program as one cycle for 7 minutes at $72^{\circ} \mathrm{C}$ for final DNA extension was performed. Finally, the reaction was terminated by holding the tubes at $4^{\circ} \mathrm{C}$ in the PCR machine as a third program. The PCR product was separated by electrophoresis on an agarose gel $(1.0 \%)$ prepared in $1 x$ Tris Acetate EDTA (TAE) and stained with ethidium bromide (final concentration of $0.5 \mu \mathrm{g} / \mathrm{ml}$ ).

\section{Data analysis}

The banding pattern obtained by RAPD-PCR was noted in the photograph. Each change observed in RAPD profiles (appearance/ disappearance of bands compared with control) 
were scored by using Sambrook standard curve [8]; Standard curves were constructed between molecular weight of the DNA marker bands(bp) and their corresponding electrophoretic mobilities ( $\mathrm{mm}$ ) (The electrophoretic mobility is the distance in $\mathrm{mm}$ between mid well and mid zone of the specific DNA band). The relationships between the presence of new bands (tumor related bands) and the histopathological subtypes were assessed using chi squared analysis for 20 samples and more, while Fisher' exact test for less than 20 cases. The acceptable level was $P<0.05$ as significant correlation. All the statistical analyses of data were carried out by SPSS software ver. 17 (IBM, US)

\section{Results}

Genomic DNAs were extracted from all studied urine samples including cancer patients and negative controls and electrophoresed in $0.7 \%$ agarose gels. Figures 1, 2 and 3 shed light upon different examples of gel electrophoresis of extracted DNA from renal cancer and healthy controls respectively.

RAPD-PCR analysis was carried out on the selected DNA samples obtained from exfoliated cells in urine of both renal cancer and healthy using Bio-A09 primer. The primer Bio-A09 produced five major normal bands of amplified fragments and were appeared in normal RAPD pattern; their molecular sizes

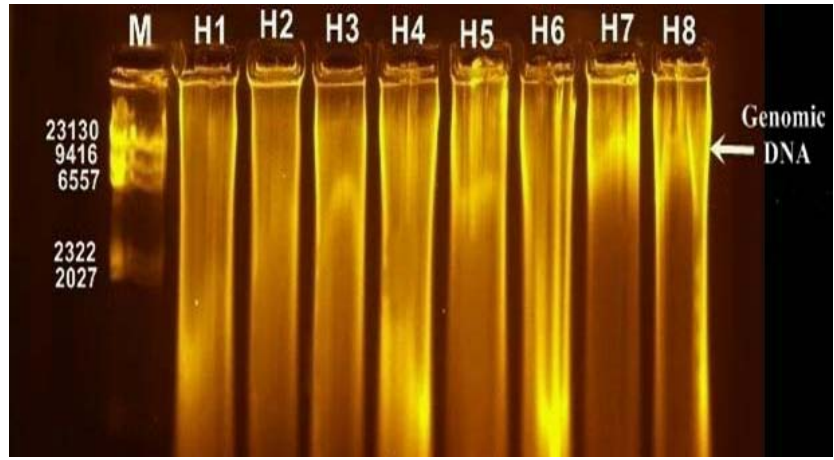

Figure 1: Gel electrophoresis of genomic DNA extraction of 8 healthy samples ( $\mathrm{H} 1$ to $\mathrm{H} 8$ ) in $0.7 \%$ TAE buffer agarose gel at $100 \mathrm{~V}$ for 1.5 hours. M: Lambda DNA Hind III-digested marker (23130-564 bp).

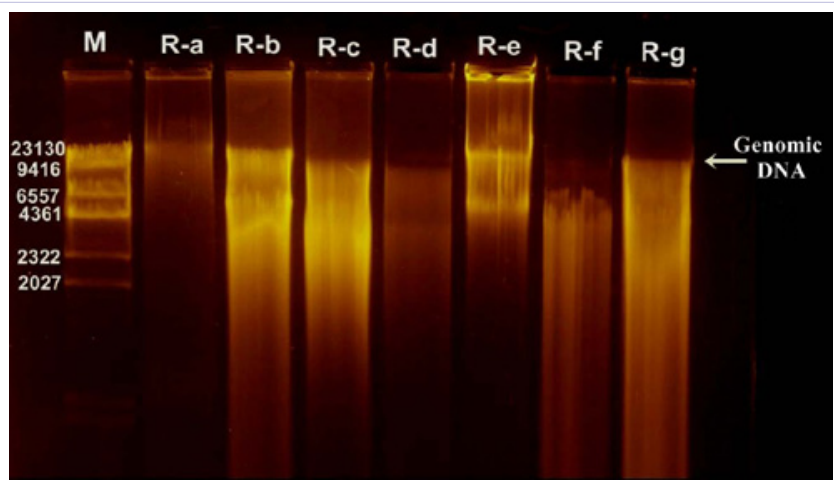

Figure 2: Gel electrophoresis of genomic DNA extraction of 7 renal cancer samples (R-a to R-g) in $0.7 \%$ agarose gel in $1 \mathrm{x}$ TAE buffer at $100 \mathrm{~V}$ for 40 minutes. M: Lambda DNA Hind III-digested marker (23130-564 bp).

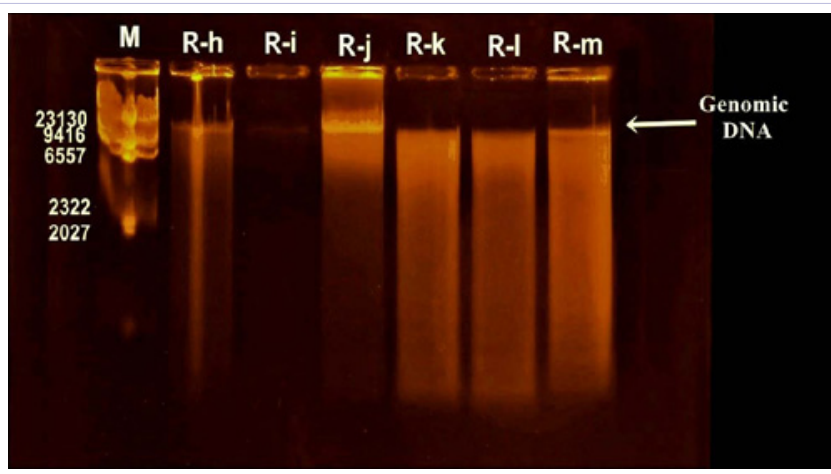

Figure 3: Gel electrophoresis of genomic DNA extraction of 6 renal cancer samples (R-h to R-m) in $0.7 \%$ agarose gel in $1 \mathrm{x}$ TAE buffer at $100 \mathrm{~V}$ for 40 minutes. M: Lambda DNA Hind III-digested marker (23130-564 bp).

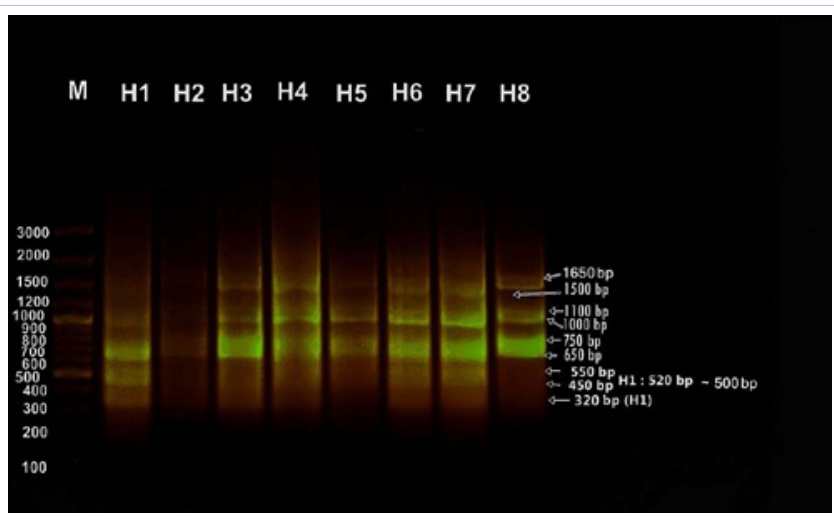

Figure 4: Gel electrophoresis of RAPD-PCR product of healthy DNA (H1-H8) amplified by primer Bio-A09. Electrophoresis was performed on $(1 \%)$ agarose gel in $1 \mathrm{x}$ TAE buffer at 80 volt for 2 hrs. M: Gene Ruler ${ }^{\mathrm{TM}}$ 100 bp plus DNA ladder marker (3000-100) bp.

were $650,750,1000,1100,1500$ bp respectively (Figure 4). The primer produced thirteen different tumor related bands, and there molecular sizes were $180,250,350,400,500,550,900$, 1250, 1300, 1400, 1650, 1700and 1900 bp (Table 2, Figure 5-13). However normal white blood cells and epithelial cells which present in patients urine are potentially in a very low quantities if compared to the exfoliated tumor cells quantities. So; the genomic DNA and RAPD-PCR DNA product of that normal white blood cells and epithelial cells is significantly negligible in relation to that of the tumor cells. The RAPD-PCR analysis of renal cancer patterns revealed loss of normal bands and appearance of new tumor related bands (Table 2).

\section{Conventional renal cell carcinoma (RCC)}

Clear renal cell carcinoma (clear RCC): Eight new tumor related bands appeared with molecular sizes around 180, 250, $350,400,500,900,1250$ and $1400 \mathrm{bp}$. The incidence of them were $95.5 \%, 77.2 \%, 54.5 \%, 54.5 \%, 100 \%, 50 \%, 45.5 \%$ and $13.6 \%$ respectively (Figures 5,6). By running the statistical analyses (Chi-square tests) there were a significant association between the presence of $180\left(X^{2}=25.5, p<0.001\right), 250\left(X^{2}=14.26, p\right.$ $<0.001), 350\left(X^{2}=7.273, p=0.007\right), 400\left(X^{2}=7.273, p=0.007\right)$, 


\begin{tabular}{|c|c|c|c|c|c|c|c|c|c|c|c|c|c|c|c|c|c|c|c|}
\hline & \multicolumn{18}{|c|}{ Percentages of amplified DNA bands } \\
\hline & & \multicolumn{13}{|c|}{ Tumor bands } & \multicolumn{5}{|c|}{ Normal bands } \\
\hline $\begin{array}{l}\text { Histo- } \\
\text { pathological } \\
\text { types }\end{array}$ & $\begin{array}{l}\text { N o.o f } \\
\text { tested }\end{array}$ & $\begin{array}{l}\text { مे } \\
0 \\
\infty \\
-1\end{array}$ & ลิ & 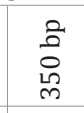 & $\begin{array}{l}\text { 8े } \\
\text { के }\end{array}$ & 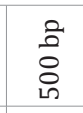 & 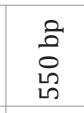 & 各 & $\begin{array}{l}0 \\
\text { in } \\
\text { N } \\
-18\end{array}$ & $\begin{array}{l}0 \\
0 \\
m \\
-1\end{array}$ & $\begin{array}{l}0 \\
0 \\
+1 \\
-1\end{array}$ & $\begin{array}{l}0 \\
10 \\
0 \\
-18\end{array}$ & $\begin{array}{l}0 \\
0 \\
1 \\
-1\end{array}$ & $\begin{array}{l}0 \\
0 \\
a \\
-1\end{array}$ & 各 & 官 & $\begin{array}{l}0 \\
0 \\
0 \\
-1 \\
0\end{array}$ & $\begin{array}{l}0 \\
0 \\
-1 \\
-1\end{array}$ & $\begin{array}{l}0 \\
0 \\
\text { ñ } \\
-1\end{array}$ \\
\hline Clear RCC & 22 & 95.5 & 77.2 & 54.5 & 54.5 & 100.0 & 9.0 & 50.0 & 45.5 & 4.5 & 13.6 & 0.0 & 0.0 & 0.0 & 45.4 & 72.7 & 72.7 & 59.1 & 33.3 \\
\hline Papillar & 18 & 44.4 & 44.4 & 16.7 & 27.8 & 100.0 & 5.6 & 16.6 & 44.4 & 5.6 & 0.0 & 0.0 & 0.0 & 33.3 & 22.2 & 11.0 & 27.8 & 33.3 & 44.4 \\
\hline $\begin{array}{l}\text { Chromophobe } \\
\text { RCC }\end{array}$ & 2 & 0.0 & 0.0 & 0.0 & 0.0 & 0.0 & 100.0 & 50.0 & 0.0 & 0.0 & 100.0 & 100.0 & 0.0 & 0.0 & 0.0 & 50.0 & 100.0 & 50.0 & 0.0 \\
\hline TCC & 5 & 0.0 & 0.0 & 60.0 & 40.0 & 100 & 0.0 & 0.0 & 0.0 & 60.0 & 0.0 & 0.0 & 100.0 & 40.0 & 0.0 & 40.0 & 60.0 & 100.0 & 0.0 \\
\hline Wilms & 2 & 0.0 & م0 & 0.0 & & 0.0 & 100.0 & 0.0 & 0.0 & 0.0 & 100.0 & 0.0 & 100.0 & 0.0 & 0.0 & 0.0 & 0.0 & 0.0 & 0.0 \\
\hline Renal sarcoma & 1 & & & & & & 0.0 & 0.0 & 0.0 & 0.0 & 0.0 & 0.0 & 0.0 & 100.0 & 0.0 & & 0.0 & 0.0 & 0.0 \\
\hline $\begin{array}{l}\text { Renal } \\
\text { oncocytoma }\end{array}$ & 2 & 0.0 & 100.0 & 100.0 & 100.0 & 100.0 & 0.0 & 0.0 & 0.0 & 50.0 & 0.0 & 0.0 & 0.0 & 0.0 & 50.0 & 100.0 & 100.0 & 100.0 & 100.0 \\
\hline Healthy controls & 8 & 0.0 & 0.0 & 0.0 & 0.0 & 12.5 & 0.0 & 0.0 & 0.0 & 0.0 & 0.0 & 12.5 & 0.0 & 0.0 & 100 & 100 & 100 & 75.0 & 62.5 \\
\hline
\end{tabular}

Table 2: Percentages of amplified DNA fragments generated by Bio- A09 in renal cancer patients and controls. Sizes of DNA bands are indicated in base pairs (bp).

$500\left(X^{2}=25.12, p<0.001\right), 900\left(X^{2}=6.32, p=0.012\right)$ and $1250\left(X^{2}\right.$ $=5.455, p=0.02$ ) bp bands and this clear RCC histosubtype. On the other hand, there is no significant association between this histosubtype and the presence of $1400\left(X^{2}=1.21, p=0.271\right) \mathrm{bp}$ band.

\section{Papillary renal cell carcinoma (PRCC)}

The study results showed the incidence of eight tumor related bands of 180, 250,350,400, 500, 900, 1250 and $1900 \mathrm{bps}$ in the genomic PRCC were 44.4\%, 44.4\%, 16.7\%, 27.8\%, 100\%, $16.65,44.4 \%$ and $33.3 \%$ respectively (Figures 7,8 ). By running the statistical analyses (Chi-square tests) there were a significant association between the presence of $180\left(X^{2}=5.136, p=0.023\right)$ $250\left(X^{2}=5.136, p=0.023\right), 500\left(X^{2}=21.55, p<0.001\right)$, and 1250 $\left(X^{2}=5.136, p=0.023\right)$ bp bands and PRCC histosubtype. On the other hand, there is no significant association between this histosubtype and the presence of $350\left(X^{2}=1.507, p=0.22\right), 400\left(X^{2}\right.$ $=2.751, p=0.097), 900\left(X^{2}=3.46, p=0.063\right)$ and $1900\left(X^{2}=3.46\right.$, $p=0.063$ ) bp bands.

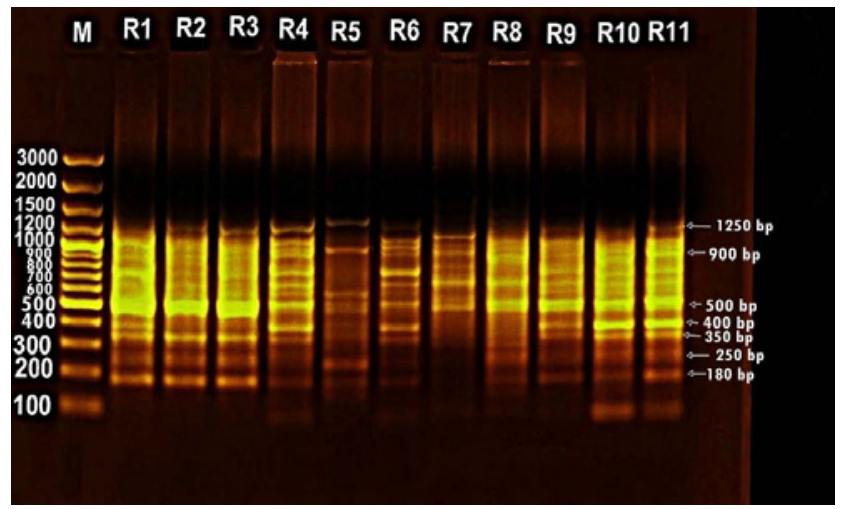

Figure 5: Gel electrophoresis of RAPD-PCR product of clear renal cell carcinoma samples (R1-R11) amplified by primer Bio-A09. Electrophoresis was performed on (1\%) agarose gel in $1 \mathrm{x}$ TAE buffer at 80 volt for 1.5 hrs. M: Gene Ruler ${ }^{\text {TM }} 100$ bp plus DNA Ladder (3000-100 bp).

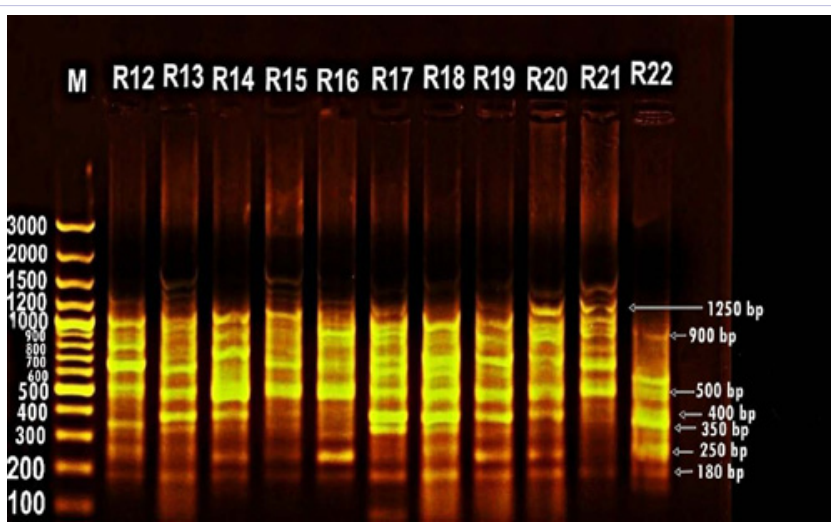

Figure 6: Gel electrophoresis of RAPD-PCR product of clear renal carcinoma samples (R12-R22) amplified by primer Bio-A09. Electrophoresis was performed on $(1 \%)$ agarose gel in $1 \mathrm{x}$ TAE buffer at 80 volt for 1.5 hrs. M: Gene Ruler ${ }^{\text {TM }} 100$ bp plus DNA ladder marker (3000-100 bp).

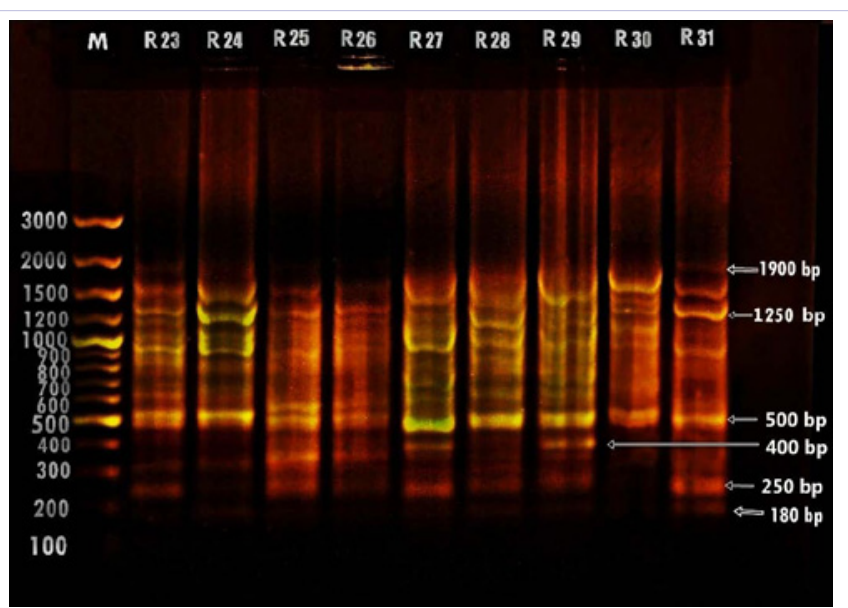

Figure 7: Gel electrophoresis of RAPD-PCR product of papillary renal carcinoma (R23-R31) amplified by primer Bio-A09. Electrophoresis was performed on (1\%) agarose gel in $1 \mathrm{x}$ TAE buffer at 90 volt for 1.15 hrs. M: Gene Ruler 100 bp plus DNA ladder marker (3000-100 bp).

Citation: El-Far M, Abol-Enein H, Zakaria A, El-Gedamy M (2013) Detection of Genomic Instability in Renal Cancer by Random Amplified Polymorphic DNA Analysis from Urine Sample as a Non-invasive Method: Potential Use in Diagnosis. Cancer Sci Res Open 


\section{Chromophobe renal cell carcinoma}

Three major significant bands ( $p=0.02$, using Fisher' exact test) with molecular sizes 550, 1400 and 1650 bps appeared in all of the samples (Figure 9). On the other hand band $900 \mathrm{bp}$ not considered to be a significant band $(p=0.2)$.

\section{Transitional cell carcinoma of renal pelvis (renal TCC)}

Five new tumor related bands appeared with molecular sizes $350,400,500,1300,1700$ and $1900 \mathrm{bp}$. The incidence of them were $60 \%, 40 \%, 100 \%, 60 \%, 100 \%$, and $40 \%$ respectively. Fisher's exact test finds an evidence of association between the presence of $350,500,1300$, and $1700 \mathrm{bp}$ bands and TCC ( $p$-values $0.035,0.005,0.035$ and 0.001 respectively). Both $400(p=0.128)$ and $1900(p=0.128)$ bp bands considered to be non significant bands (Figure 10).

\section{Wilms' tumor (Nephroblastoma)}

Three significant bands with molecular sizes 550, 1400 and 1700 bp ( $p$ values $0.022,0.022$ and 0.022 , using Fisher' exact test) are appeared (Figure 11)

\section{Renal Sarcoma}

It was found an absence of all the normal bands. It is also worth mentioning that we have only one sample of this histotype, so it is difficult to detect significances or a marker bands. A tumor related band with molecular size $1900 \mathrm{bp}$ appeared in this sample (Figure 12).

\section{Renal oncocytoma}

The pattern of renal oncocytoma expressed high similarity to the healthy pattern in their major normal bands $650(50 \%)$ $750(100 \%), 1000(100 \%), 1100(100 \%)$ and $1500(100 \%)$. In addition, Fisher's exact test finds no evidence of association between tumor related bands $250(p=0.022), 350(p=0.022)$, $400(p=0.022), 500(p=0.022)$ and $1300 \mathrm{bp}(p=0.2)$ and renal oncocytoma tumor (Figure 13).

\section{Discussion}

The randomly amplified polymorphic DNA (RAPD) protocol was reliable, simple to set up, fast and large areas of genomic DNA

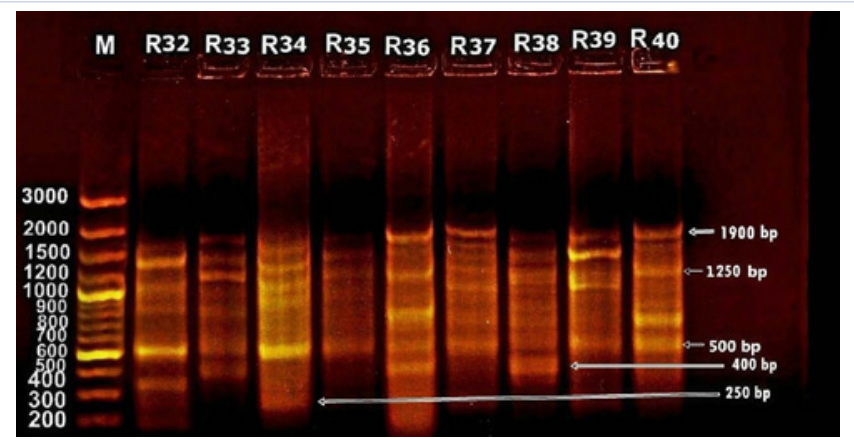

Figure 8: Gel electrophoresis of RAPD-PCR product of papillary RCC (R32 - R40) amplified by primer Bio-A09. Electrophoresis was performed on (1\%) agarose gel in $1 \mathrm{x}$ TAE buffer at 80 volt for $1.5 \mathrm{hrs}$. M: Gene Ruler ${ }^{\mathrm{TM}} 100 \mathrm{bp}$ plus DNA ladder marker (3000-100 bp).

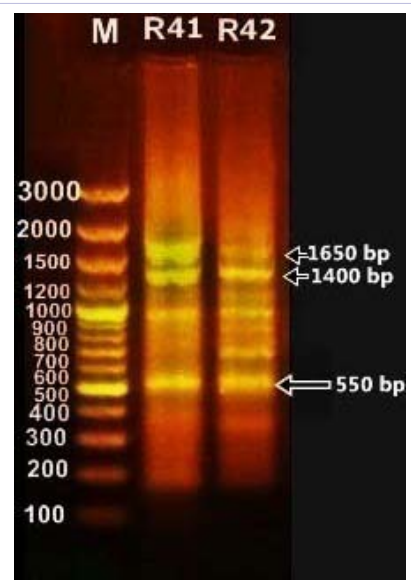

Figure 9: Gel electrophoresis of RAPD-PCR product of chromophobe renal cell carcinoma (R41-42) amplified by primer Bio-A09. Electrophoresis was performed on $(1 \%)$ agarose gel in $1 \mathrm{x}$ TAE buffer at 80 volt for 2 hrs. M: Gene Ruler ${ }^{\text {TM }} 100$ bp plus DNA ladder marker (3000-100 bp).

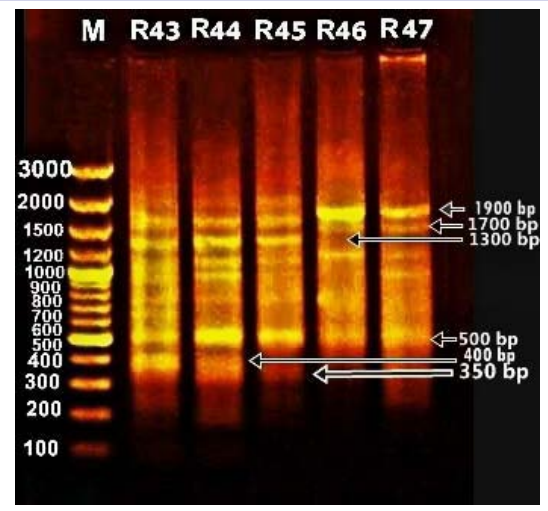

Figure 10: Gel electrophoresis of RAPD-PCR product of transitional renal cell carcinoma (R43-47) amplified by primer Bio-A09. Electrophoresis was performed on (1\%) agarose gel in $1 \mathrm{x}$ TAE buffer at 80 volt for 2 hrs. M: Gene Ruler ${ }^{\mathrm{TM}} 100$ bp plus DNA ladder marker (3000-100 bp).

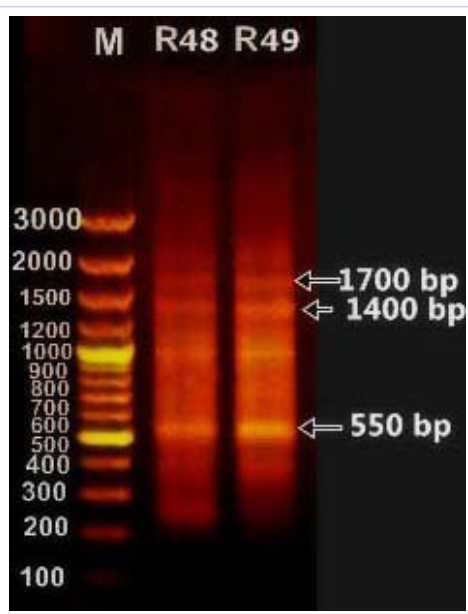

Figure 11: Gel electrophoresis of RAPD-PCR product of Wilms' tumor (R48-R49) amplified by primer Bio-A09. Electrophoresis was performed on $(1 \%)$ agarose gel in $1 \mathrm{x}$ TAE buffer at 80 volt for 2 hrs. M: Gene Ruler ${ }^{\text {TM }} 100$ bp plus DNA Ladder Marker (3000-100 bp). 


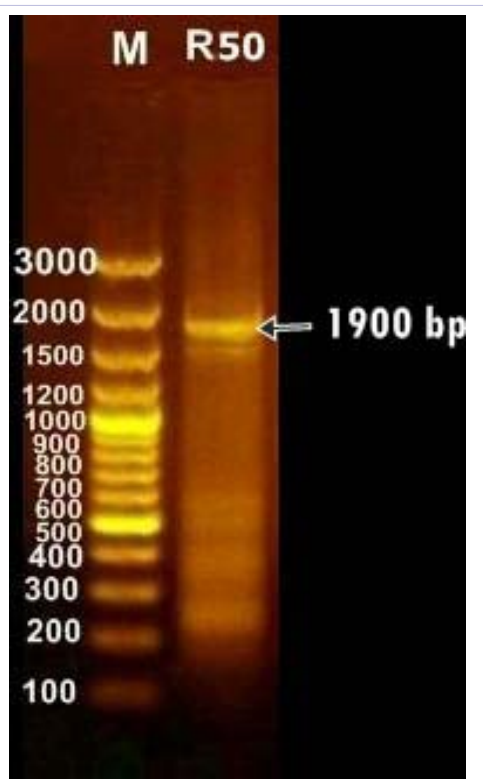

Figure 12: Gel electrophoresis of RAPD-PCR product of renal sarcoma (R50) amplified by primer Bio-A09. Electrophoresis was performed on (1\%) agarose gel in $1 \mathrm{x}$ TAE buffer at 80 volt for 2 hrs. M: Gene Ruler ${ }^{\text {TM }}$ $100 \mathrm{bp}$ plus DNA ladder (3000-100 bp)

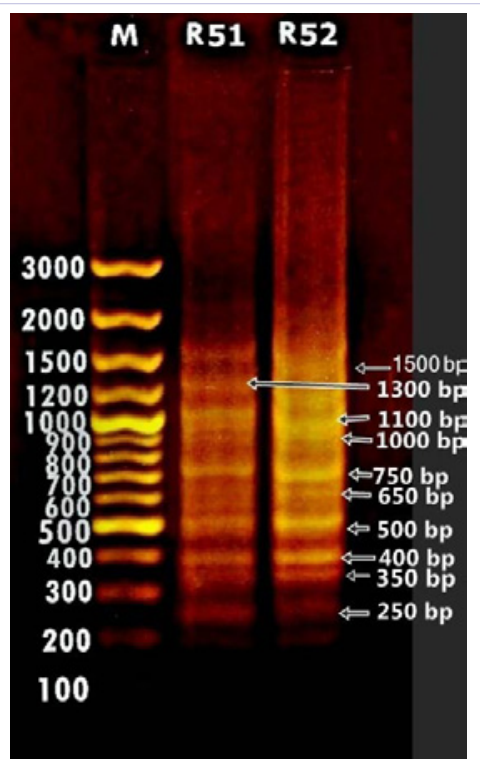

Figure 13: Gel electrophoresis of RAPD-PCR amplification pattern of renal oncocytoma (R51-R52) amplified by primer Bio-A09. Electrophoresis was performed on (1\%) agarose gel in $1 \mathrm{x}$ TAE at 90 volt for 1.15 hrs. M: Gene Ruler ${ }^{\text {TM }} 100$ bp plus DNA ladder (3000-100 bp).

screened. The RAPD-PCR amplification with a single decamer primer is affected essentially with Primer, DNA template and reaction conditions [9]. So that these advantages in comparison to other DNA fingerprinting method, such as restriction fragment length polymorphism (RFLP) that need larger quantity of pure DNA, target gene or few loci of the gene and some information's about DNA restriction sites and restriction enzymes. So the RAPD method has the potential to detect a wide range of DNA damage as well as mutations [10]. To our knowledge, our study is the unique study that applying the RAPD-PCR test to detect the genomic instability in renal cancer histopathological types. Other studies have been successfully used RAPD assay to detect the genomic instability in brain tumors [11], lung cancer [12], breast cancer [13], colon cancers [14], head and neck squamous cell carcinoma [15], acute lymphoblastic leukemia [16], hepatocellullar carcinoma [17], astrocytic tumors [18], skin cancers [19] and pituitary adenomas [20]. The study of Ibrahim et al. (2010) used the same primer, which we already used in our study, in diagnosis of acute lymphoblastic leukemia. It was found that, a band which represents DNA fragment of $980 \mathrm{bp}$ was absent in normal individual but it was present in $55.6 \%$ of all leukemia patients. In our study we used the same synthetic primer (5'-GGGTAACGCC-3') and showed the possibility of using this primer to identify the genomic DNA instability of renal cancer patients when compared with normal individuals. The observation of newly appeared DNA fragment of $500 \mathrm{bp}$ (marker band) in the tumor samples was of $90.4 \%$ of the screened cases. In other words, a $500 \mathrm{bp}$ band was significant band in clear RCC $(P<0.001)$, papillary RCC $(P<0.001)$, renal TCC $(P=0.005)$ and renal oncocytoma $(P=0.022)$. Moreover, the appearing of 180 $\left(X^{2}=13.15, p<0.001\right), 250\left(X^{2}=9.524, p=0.002\right)$, and $1250\left(X^{2}=\right.$ 5.357, $p=0.021$ ) bp bands in RAPD-PCR product of conventional RCC might suggest the possibility of using these DNA fragments as molecular markers for detection of the genomic instability of this major type of renal carcinoma. Also we suggested 1700 bp band as a marker band for both renal TCC $(p=0.001)$ and Wilms' tumor $(p=0.022)$. The pattern of renal oncocytoma (benign tumor) expressed high similarity to the healthy pattern. So, our present study agrees to the study of Liping et al. (2003) in proving the role of RAPD-PCR in diagnosis of tumor development generally. In addition, the gender difference by using RAPD-PCR method was not one of our study goals in the present study that is why it was not addressed or discussed. Moreover, further work is required on larger sample of normal individuals and cancer patients to calculate the specificity and the sensitivity for such novel diagnostic biomarkers using other large scale oriented statistical methods. Furthermore, cloning and sequencing of appeared marker bands would have been nice to know which specific genes are changed in urine samples from cancer patients compared to the controls and compare or combine it with some kinds of diagnostic biochemical tools done in other tumors [21,22].

\section{Conclusion}

RAPD decamer primer Bio-A09 produced 500 DNA fragments in conventional RCC (clear and papillary) and renal TCC type in addition to 1700 DNA fragments in in Wilms' tumor and renal TCC, these DNA fragments were not detected in tested normal individuals. Also, convention RCC characterized by three bands with molecular sizes 180, 250 and $1250 \mathrm{bp}$ not found in other types. The amplified DNA fragment might be proved useful for further development of molecular markers for diagnosis of renal cancer. The study gives new evidence of potential promise of RAPD-PCR analysis in cancer research for detecting and selecting 
novel genomic markers and proving the role of RAPD-PCR in diagnosis of tumor development generally.

\section{References}

1. Pascual D, Borque A (2008) Epidemiology of kidney cancer. Adv Urol J $4: 1-7$.

2. Mokhtar NM, Gouda I, Adel I (2007) Cancer pathology registry (20032004) and time trend analysis. Department of Pathology, Egyptian NCI

3. Butler JM (2005) Forensic DNA typing: biology, technology, and genetics of STR markers. (2ndedn), Elsevier Academic Press, New York.

4. Kumar P, Gupta VK, Misra AK, Modi DR, Pandey BK (2009) Potential of molecular markers in plant biotechnology. Plant Omics J 2(4): 141 162.

5. Monteleone I, Ferrazzini D, Belletti P (2006). Effectiveness of neutral RAPD markers to detect genetic divergence between the subspecies uncinata and mugo of Pinus mugo Turra. Silva Fennica J 40(3): 391406.

6. Ausubel FM, Brent R, Kingston RE, Moor DD, Seidman JG, et al. (2003) Current Protocols in Molecular Biology. (3rdedn). John Wiley \& Sons, Inc., New York

7. Maniatis T, Fritsch EF, Sambrook J (1983). Molecular cloning: A laboratory manual. Cold Spring Harbor, New York

8. Sambrook J, Russell DW (2001) Molecular cloning: A laboratory manual. (3rdedn), Cold Spring Harbor Laboratory Press, New York.

9. Faddagh MS, Hussain AN, Al-Badran AI (2012) DNA finger printing of eight cyprinid fish species of Iraqi inland waters using RAPD-PCR technique. Advances in Life Sciences J 2(2): 9-16.

10. Fayazi J, Moradi M, Rahmani G, Ashtyani R, Gal-ledari H (2006) Genetic differentiation and phylogenetic relationships among Barbus xanthopterus (Cyprinidae) populations in southwest of Iran using mitochondrial DNA markers. Pakistan J Biol Sci 9(12): 2249-2254.

11. Dil-Afroze A, Anjan M, Irshad MS, Subrata S, Chitra S, et al. (1998) Genetic alterations in brain tumors identified by RAPD analysis. Gene J 206(1): 45-48.

12. Ong TM, Song B, Qian HW, Wu ZL, Whong WZ (1998) Detection of genomic instability in lung cancer tissues by random amplified polymorphic DNA analysis. Carcinogenesis J 19: 233-235.

13. Singh KP, Roy D (2001) Identification of novel breast tumor-specific mutation(s) in the q11.2 region of chromosome 17 by RAPD/AP-PCR fingerprinting. Gene J 269(1-2): 33-43.

14. Luo L, Li B, Pretlow TP (2003) DNA alterations in human aberrant crypt foci and colon cancers by random primed polymerase chain reaction. Cancer Res J 63(19): 6166-6169.

15. Maeda T, Jikko A, Hiranuma H, Fuchihata H (1999) Analysis of genomic instability in squamous cell carcinoma of the head and neck using the random amplified polymorphic DNA method. Cancer Letter J 138(1): $183-188$.

16. Ibrahim MA, Saleh N, Archoukieh E, Al-Obaide WH (2010) Detection of novel genomic polymorphism in acute lymphoblastic leukemia by random amplified polymorphic DNA analysis. Inter. J of Cancer Res 6(1): 19-26.

17.Xian ZH, Cong WM, Zhang SH, Wu MC (2005) Genetic alteration of hepatocellular carcinoma by random amplified polymorphic DNA analysis and cloning sequencing of tumor differential DNA fragment. World Gastroenterol J 11: 4102-4107.

18. Kunzang C, Anjan M, Sachin P, Tapasya S, Parthaprasad C, et al. (2009). Frequent loss of heterozygosity and altered expression of the candidate tumor suppressor gene 'FAT' in human astrocytic tumors. BMC Cancer J 9: 1-15.

19. Ribeiro GR, Francisco G, Teixeira LV, Romao-Correia RF, Sanches JA, et al. (2004) Repetitive DNA alterations in human skin cancers. Dermatol Sci J 36(2): 79-86.

20. Jotwani G, Misra A, Chattopadhyay P, Sarkar C, Mahapatra AK, et al (2004) Genetic heterogeneity and alterations in chromosome 9 loci in a localized region of a functional pituitary adenoma. Cancer Genet. Cytogenet J 125(1): 41-45

21. El Far MA, Atwa MA, Yahya RS, El Basuni MA (2006) Evaluation of serum levels of p53 in hepatocellular carcinoma in Egypt. Clin Chem Lab Med J 44(5): 653-656.

22. Attallah AM, El-Far M, Abdel Malak CA, Zahran F, Farid K, et al (2011) Evaluation of cytokeratin-1 in the diagnosis of hepatocellular carcinoma. Clin Chim Acta 412(23-24): 2310-2315. 